\title{
Théophile Gautier, Euvres complètes, Romans, contes et nouvelles, tome 3, Partie carrée, Jean et Jeannette
}

\section{Lise Sabourin}

\section{(2) OpenEdition}

1 Journals

\section{Édition électronique}

URL : http://journals.openedition.org/studifrancesi/1408

DOI : 10.4000/studifrancesi. 1408

ISSN : 2427-5856

Éditeur

Rosenberg \& Sellier

\section{Édition imprimée}

Date de publication : 1 décembre 2015

Pagination : 615-616

ISSN : 0039-2944

\section{Référence électronique}

Lise Sabourin, "Théophile Gautier, Euvres complètes, Romans, contes et nouvelles, tome 3, Partie carrée, Jean et Jeannette », Studi Francesi [En ligne], 177 (LIX | III) | 2015, mis en ligne le 01 décembre 2015, consulté le 10 janvier 2021. URL : http://journals.openedition.org/studifrancesi/1408 ; DOI : https:// doi.org/10.4000/studifrancesi. 1408

Ce document a été généré automatiquement le 10 janvier 2021.

\section{(c) $(1) \odot$}

Studi Francesi è distribuita con Licenza Creative Commons Attribuzione - Non commerciale - Non opere derivate 4.0 Internazionale. 


\title{
Théophile Gautier, Euvres complètes, Romans, contes et nouvelles, tome 3, Partie carrée, Jean et Jeannette
}

\author{
Lise Sabourin
}

\section{RÉFÉRENCE}

THÉOPHILE GAUTIER, CEuvres complètes, Romans, contes et nouvelles, tome 3, Partie carrée, Jean et Jeannette, texte établi, présenté et annoté par Françoise COURT-PEREZ, Paris, Honoré Champion, 2014, pp. 501.

1 Le roman Partie carrée, d'abord intitulé Les Deux Étoiles en feuilleton et première publication, avant de trouver son titre définitif chez Souverain en 1852, est marqué par la dualité de personnalités troublées en quête de leur véritable nature. Par ce steeplechase aristocratique, ce chassé-croisé de l'Angleterre à Sainte-Hélène, Gautier cherche à opérer le syncrétisme des romans d'aventures, de conspiration et d'exotisme, avec son érudition habituelle et sa fantaisie ironique. La description de la beauté pure et du pittoresque réaliste fait s'entrecroiser les rues londoniennes et les paysages orientaux, tandis que le refus du roman maritime à la Sue profite au symbolisme à la Cooper. Sur fond d'épopée napoléonienne, néantisée par l'imprécision volontaire des datations, surgit l'actualité de 1848, sans portée politique toutefois chez ce désabusé du romantisme comme de toute idéologie. Gautier préfère fuir dans un passé immémorial herméneutique ou s'évader dans un futurisme prévernien. L'Orient lui offre, par l'inspiration des planches d'Edward Moor et la traduction du Sacountalâ de Kalidasa par Chézy en 1830, et grâce aux conversations indiennes de Méry, tout ce qui convient à son goût de la volupté, de la fureur, du mystère et de l'humour.

2 Jean et Jeannette explore une autre voie du romanesque amoureux traité avec persiflage, par son goût Régence si apprécié du Doyenné dès 1834. Roman d'apprentissage, roman galant, roman de genre convergent en un pastiche rococo jouant à la pastorale de cour. 
Cette comédie de l'amour chez des grands rêvant d'une vertu absente de leurs mœurs suscite des tableaux plus plastiques qu'analytiques, inspirés de Boucher, Fragonard, Lancret et Watteau, corrigés en intérieurs plus bourgeois par Chardin, tandis que le ton relève du Molière des Précieuses ridicules ou d'un marivaudage sans profondeur: Gautier s'amuse à ressusciter le monde défunt de l'avant Révolution française, avec une cocasserie grotesque qui refuse de se laisser aller à la nostalgie.

3 Françoise Court-Perez donne une annotation très détaillée, bien utile pour mieux apprécier les allusions de cet auteur si cultivé (dommage que parfois les notes manquent de synthèse, comme découvrant des faits historiques ou culturels assez connus, ou recèlent quelques coquilles, répétitions et erreurs: Luciennes pour Louveciennes, p. 440; deux fois la même note p. 446; la Chersonèse présentée comme une ville et non une péninsule, p. 462). Mais ses introductions (pp. 11-92 et pp. 289-351) sont très éclairantes pour faire comprendre le lien entre ces deux romans parus dans «La Presse» en 1848 et 1850 quoique à la gestation fort différente, de tons si décalés, mais unis par l'amour du jeu. 